\title{
Inter-Organizational Collaboration, Knowledge Intensity, and the Sources of Innovation in the Bioscience-Technology Industries
}

\author{
Kelvin Willoughby and Peter Galvin
}

\begin{abstract}
What makes some firms more innovative than others and what determines the source of these innovations are questions that are still not adequately answered due to the complex, often esoteric, nature of the innovation process. This paper considers the effect of one externally oriented strategy (extent of formal inter-organizational linkages) and one internally oriented strategy (degree of knowledge intensity) on overall levels of innovativeness and the source of these innovations. Using data collected from firms operating in the bioscience-technology industries in both New York and Utah, our results suggest that both of these strategies have a significant effect upon innovation levels and the source of innovation (internally versus externally stimulated). Interestingly, there were few firms that undertook both of these strategies simultaneously and thus the proposed interaction effect where increased absorptive capacity (on the basis of knowledge intensity) would make external linkages even more valuable could not be discerned.
\end{abstract}

\footnotetext{
Kelvin Willoughby holds the Honeywell/W. R. Sweatt Chair in the Management of Technology at the University of Minnesota, and is Director of the Management of Technology Program in the Center for the Development of Technological Leadership. His interests lay in strategic technology management, intellectual property management, technology-based entrepreneurship, technologybased industry development, and regional economic development planning. Much of his work has focused on life-science related industries. He holds doctoral degrees in both technology studies and strategic management. He also works in the area of technology commercialization education for the U.S. Government's Federal Laboratory Consortium for Technology Transfer. He may be contacted at $<$ kelvin@umn.edu $>$.

Peter Galvin is a Senior Lecturer in the Graduate School of Management at Curtin University of Technology. He received his PhD from the University of Western Australia in 1998. His present research interests focus upon the nexus of strategy and innovation, and have included studies in the bicycle, financial services, airline and biotechnology industries. He can be contacted at <peter.galvin@gsb.curtin.edu.au>.
}

Knowledge, Technology, \& Policy, Fall 2005, Vol. 18, No. 3, pp. 56-73. 


\section{Introduction}

In 2003, Kahn et al. outlined some of the key issues that various scholars in the field of innovation and new product development felt required further research. The breadth of their list is impressive but, for the purposes of this paper, two issues are worthy of note. First, factors affecting firm level innovativeness and the sources of innovation - the focus of this paper - are both listed as important topics. As general topics, however, they are so broad that specific factors need to be highlighted as requiring research (e.g., what is the impact of leadership, size and age on the process).

The second issue that becomes obvious upon reading the paper by Kahn et al. (2003) is the enormous breadth of topics considered to be worthy of study. More than anything, this list provides some insight into the complexities of the innovation process and why, after so much research, we are still focusing upon what seem to be rather fundamental issues. It is in this vein that this study addresses fairly fundamental questions that relate back to what we consider one of the core challenges of the field - understanding the basic innovation process in different contexts, including where innovations are sourced and what drives innovativeness.

The aims of our research connect with innovation process model research, as contemporary models provide insight into a range of factors that potentially affect innovation levels, and how some of these factors may interrelate. One of the most significant shifts in innovation models over the past two decades has been the move away from seeing innovation as a process occurring within an organization, to one where external linkages are a vital part of the process. Innovation process models now incorporate horizontal and vertical linkages with external parties (Rothwell, 1992) and thus inter-organizational networks, strategic alliances, along with formal and informal linkages with customers and suppliers have all been presented as important elements in stimulating the innovation process (e.g., McAdam and McClelland, 2002). Innovation models also detail internal factors that affect innovativeness from organizational structures to the characteristics of the project leader, and these internally focused factors have featured in numerous studies (see Brown and Eisenhardt (1995) for a review).

This paper extends the work of other scholars as to what factors affect innovativeness, and as to what are the sources of innovation, by considering the relative roles of one internally oriented strategy and one externally oriented strategy of firms in the bioscience-technology industries. ${ }^{1}$ The internally oriented strategy is characterized by a focus on increasing the knowledge intensity of the firm (measured by the commitment to R\&D as a percentage of total activity), whereas the externally focused strategy is characterized by a focus the use of external collaborative linkages. We suggest that these strategies will have differing effects upon the innovativeness of firms and the source of any subsequent innovations. However, these are not mutually exclusive strategies, and we posit that an interaction effect will occur when both strategies are present. To test our propositions, data was collected from firms operating in the bioscience-technology industries in two US states. 


\section{Sources of Innovation}

Innovation studies (including innovations process models) have progressed significantly from the initial notions of innovations being driven entirely from within the firm. As early as 1969, Myers and Marquis were questioning the dominant technology push model with a finding that market pull (identifying and understanding potential customers' needs) was a more important driving force in the creation of innovations. The identification of different external parties that can stimulate innovation has grown significantly since that point. Hauschildt (1992), for example, suggested that there were four primary categories of external organizations that could help stimulate innovation within the firm. These four categories were markets (including customers and suppliers), the scientific system (including universities and research institutions), government/public authorities (including patent offices and financial centers) and mediating systems (including consultants, press, trade fairs). These external sources of innovation are strongly supported in the literature with various empirical studies independently verifying the importance of many of these different sources (e.g., Chiesa and Toletti, 2004; Alam, 2003; Herstatt and von Hippel, 1992; McAdam and McClelland, 2002).

Simultaneously, the importance of firms themselves as the drivers of innovation has not been overlooked. Considerable research has been undertaken that considers issues as diverse as the organization of work (team composition, structure and communication) and project leader characteristics, to how the 'fuzzy front end' of the process can best be managed (Clark and Wheelwright, 1992; Eisenhardt and Tabrizi, 1995; Khurana and Rosenthal, 1998).

The above-mentioned studies imply that innovations come from a number of sources and develop in a number of ways. They do little, however, to explain why innovations in some firms/industries tend to be internally or externally stimulated. To date, the most significant work as to the source of innovation comes from von Hippel (1988). Here von Hippel (1988) studied a number of industries that differ significantly in terms of the percentage of innovations that were stimulated by users or suppliers. The industries vary between 6 percent of innovations being stimulated from external sources (tractor shovel industry) to 90 percent from external sources (pultrusion process industry). His explanation as to what determines the primary source of innovation is rooted in basic economics, whereby the group that believes that they stand to benefit most from the economic rents generated by an innovation will tend to be the primary innovation driver. For example, if airlines (as users of aircraft) believe that greater fuel efficiency will generate the greatest economic rents to them, then they will be a source of innovation to the aircraft industry.

Von Hippel's hypothesis of economic rents driving the innovation process is supported by his data. However, as part of his hypothesis he posits two necessary preconditions. Firstly, that innovators find it difficult and/or expensive to switch their roles (as a supplier, manufacturer or user) and, secondly, that they have poor ability to capture rent by licensing their innovation-related knowledge to others (1988: 44). In many parts of the bioscience-technology industry (e.g., biotechnology), these conditions to not apply. Firstly, it is highly plausible and regularly observed that firms do move from being a supplier (of intellectual property) to 
becoming a manufacturer (personally using this knowledge). Furthermore, the distinction between suppliers, manufacturers and users is not clear, as a firm may be supplier to one firm but, in so doing, be a manufacturer and may actually be a user of another technology biotechnology product. In regards to von Hippel's (1988) second point, markets for technology are becoming more common (including in the bioscience-technology industry) as more and more licenses are being granted on the basis of established patents (Arora, Fosfuri, and Gambardella, 2001).

As von Hippel's (1988) economic rents model of who drives the innovation process would seem to not be applicable in the bioscience-technology industries, our research set out to study internally and externally oriented strategies and their effect both upon overall firm innovativeness and the source of these innovations. The externally oriented variable is inter-organizational collaboration and the internally oriented variable is the level of investment in R\&D capabilities.

\section{Inter-organizational Collaboration}

As innovation is such a complex and uncertain activity it commonly requires input from a range of external sources - often through inter-firm collaboration (Dodgson, 1994). This greater emphasis on collaboration has seen innovation models move from an internal orientation to a focus upon the necessity for both horizontal and vertical linkages in more contemporary innovation process models (e.g., Teece, 1989; Rothwell, 1992; Josty, 1990; Tang, 1998). For example, Rothwell (1992) introduces what he refers to as the Systems Integration and Networking (SIN) model of innovation. It emphasizes,

Fully integrated parallel development ... Strong linkages with leading edge customers ('customer focus' at the forefront of strategy). Strategic integration with primary suppliers including co-development of new products ... Horizontal linkages: joint ventures; collaborative research groupings; collaborative marketing arrangements, etc. Emphasis on corporate flexibility and speed of development ... (1992: 236).

This theoretical emphasis on collaborative mechanisms to improve innovation levels has been followed up empirically. A number of empirical studies have shown the positive effects upon innovation of inter-organizational networks, strategic alliances, joint ventures, membership of industry associations and working with customers (e.g., Freeman, 1991; Goes and Park, 1997; Sunman, 1987; von Hippel, 1978).

Given that collaboration involves the voluntary partnering of firms through which durable exchange, sharing, or co-development of new products and technologies can take place (Gulati, 1995), it is reasonable to expect that higher levels of collaboration will lead to firms with high levels of collaboration being (a) more innovative and (b) that these innovations will primarily be externally stimulated. One of the major reasons why collaboration is occurring is to assist firms in the learning or knowledge generation process (as a necessary part of innovation) (Kogut, 1988; Hamel, 1991; Khanna, Gulati and Nohria, 1998; Mowery, Oxley, and Silverman, 1996). Osland and Yaprak (1995), in discussing strategic alliances, state that collaboration, as a means to learn from a partner, can be a faster and more effective 
way of learning. Certainly complex skills based upon tacit knowledge may be difficult to acquire or develop internally and thus collaboration represents a shortcut to acquiring such knowledge.

Studies such as those by Shaw (1993) and Goes and Park (1997) have demonstrated the importance of external linkages in the medical/biosciences industries, and such studies have found that numerous innovations have been developed on the basis of collaborative linkages. While they did not set out to study the effect of collaboration on innovativeness and the source of these innovations, it is likely that high levels of collaboration lead to high levels of externally stimulated innovations. Thus, it is suggested in this paper that high levels of collaboration will lead to more innovations and that these innovations will be primarily externally stimulated.

Hypothesis 1a: Firms with high levels of external collaboration will be more innovative.

Hypothesis $1 b$ : Firms with high levels of external collaboration will produce more innovations that are externally stimulated.

\section{Knowledge Intensity}

Nonaka (1994) suggests that innovation can be conceptualized as a process in which an organization creates and defines problems and then actively develops new knowledge that can be applied to solve these problems. In this context, effective knowledge development and utilization is likely to form the basis of a competitive advantage, particularly in high technology industries where innovation is often a critical competitive dimension. It is this focus on knowledge as the source of competitive advantage that forms the underlying focus in the emerging 'knowledge based view' of the firm; and Grant (1996), for instance, suggests that the performance of firms is entirely dependent upon the knowledge that resides in the firm. In relation to innovation, Nonaka and Takeushi (1995) posit that organizations that are very innovative are highly proficient at knowledge acquisition, codification and transfer.

What constitutes knowledge and how it is created and transferred is a complex area that has been subject to considerable theorizing (e.g., von Krogh, Roos, and Slocum, 1994). Our paper does not seek to extend this basic debate any further; but rather we approached this study in the hope of differentiating between different levels of investment in knowledge development made by firms, and exploring the impact that such variations have on the creation of product innovations. Knowledge obviously exists within firms in relation to all stages of the value chain, but we were specifically interested in the knowledge relating to R\&D that underpins product innovations. Firms that invested heavily in R\&D are therefore categorized as being knowledge intensive.

As a side issue, describing firms that invest heavily in $R \& D$ activities as being knowledge intensive might perhaps be thought of by some commentators as being inconsistent with the notion of knowledge supporting all aspects of an organization's operations. Yet knowledge intensity, in the literature, is often correlated with R\&D 
intensity, as illustrated by Willoughby (2004) who suggests that the biotechnology industry is a knowledge intensive industry on the basis of very significant R\&D activities within the industry. Thus, $\mathrm{R} \& \mathrm{D}$ intensity is really a proxy for knowledge intensity. Defining knowledge intensity in this manner, however, is not inconsistent with the limited literature that covers this concept (e.g., Autio, Sapienza, and Almeida, 2000; Willoughby, 2004).

Being knowledge intensive (through making heavy investments in R\&D) is likely to provide firms with considerable opportunities to innovate internally. This was certainly the underlying logic of the initial linear models on the innovation process; and many of the contemporary innovation models also rely upon knowledge as the internal innovation driver. From a practical perspective, many, if not the majority of firms in high technology industries (and certainly the bioscience-technology industries covered in this research), have internal R\&D departments to help in the development of new knowledge that will lead to innovations. On the basic of that observation we therefore hypothesize that knowledge intensive firms will be more innovative and that the resulting innovations will be internally sourced.

Hypothesis 2a: Firms that are knowledge intensive (i.e., that invest significantly in R\&D) will be more innovative.

Hypothesis 2b: Firms that are knowledge intensive (i.e., that invest significantly in R\&D) will produce more innovations that are internally stimulated.

\section{Interaction Effects}

The externally oriented strategy of developing extensive inter-firm linkages, and the internally oriented strategy of investing in R\&D, are not mutually exclusive strategies. Rather they can be undertaken simultaneously; and it is when they are used together that we expect the strongest effects to occur. As previously detailed, external linkages with other organizations can form an important source of potential innovations. However, in a world where information is cheap and where we are likely to be subject to too much information rather than too little, discerning the value of some information and incorporating this information into the firm's knowledge base is a continual challenge. Therefore, those firms with superior knowledge stocks are likely to be in the best position to understand the value of some of the information made available through external linkages and use this in developing an innovation.

Innovation is a complex process as the cognitive processes that underlie it are idiosyncratic and rarely able to be made explicit. Knowledge (or at least data that becomes knowledge upon incorporation into a larger mental model that provides contextualization and understanding) is a key component, and for that reason, the innovation models and sources of innovation research have shown that there is a plethora of different knowledge sources that lie behind different innovations. However, the ability of firms to acquire, assimilate and exploit knowledge relies upon the absorptive capacity of the firm (Cohen and Levinthal, 1990). That is, a firm's existing knowledge base affects the firm's ability to search and recognize the value of new knowledge as well as assimilate this new knowledge into the firm's operations. 
The absorptive capacity of a firm can potentially affect the ability of a firm to use both internally and externally generated knowledge in the development of innovation. However, as knowledge creation is a cumulative and path-dependent process, the potential value of internally generated knowledge is likely to be recognized and it should be able to be applied effectively within this context. It is possible that knowledge generated by one individual or group may actually prove to be useful to another group in an organization working on an alternative problem, but this is likely to be the exception. Instead, it is the knowledge that flows from external sources that is most likely to be at risk of being unable to be assimilated and effectively utilized because of the absorptive capacity of the firm. Therefore, the value of any external linkages is not the amount of knowledge that they are able to provide, but rather the amount of knowledge provided that can be effectively assimilated and applied on the basis of the firm's own absorptive capacity.

A firm's absorptive capacity depends upon its own knowledge base, as well as its capabilities to assimilate and convert external knowledge to solve existing problems (Cohen and Levinthal, 1990). In essence, the greater a firm's existing knowledge base, the greater its absorptive capacity. Therefore, firms that are classified as knowledge intensive on the basis of their investments in R\&D are more likely to be innovative on two counts. Firstly, such investments are likely to stimulate internal innovations simply through the R\&D process. However, it also increases the probability of knowledge received from external sources being assimilated and applied within the firm. That is, the external linkages become more fruitful sources of innovation on the basis that more of the resulting knowledge can be applied to creating innovations. Certainly, empirical tests support this position, demonstrating that higher levels of R\&D improve a firm's ability to exploit sources of knowledge from outside its boundaries (Gambardella, 1992; Mowery, Oxley and Silverman, 1996). Therefore, we propose that firms that exhibit both high levels of collaboration and high levels of knowledge intensity will be the most innovative firms, and that because the increased absorptive capacity (from being knowledge intensive) allows more knowledge to be assimilated from external linkages, innovations in such firms will be predominantly externally sourced.

Hypothesis 3a: Firms that are knowledge intensive and that have high levels of external collaboration will be the most innovative.

Hypothesis 3b: Firms that are knowledge intensive and that have high levels of external collaboration will produce more innovations that are externally stimulated.

\section{Methods}

\section{Sample}

The data for this paper came from two related studies. The first was administered through the State University of New York at Stony Brook, in association with the New York Biotechnology Association. The second study, covering Utah's Bioscience Technology industry, was conducted during the latter part of 1998, in asso- 
ciation with the Utah Life Sciences Association. It included data on 116 dedicated bioscience firms. The sample consisted of 11 biotechnology firms, 11 pharmaceutical firms, 59 medical devices firms, 6 life-systems technology firms and 29 that operated in multiple fields. Many firms operated in one area primarily, but had some activities that crossed industry boundaries.

The New York data was collected in late 1996 and covered 127 firms. Of these, 28 firms considered themselves to be biotechnology firms, 19 pharmaceutical firms, 36 medical devices firms and 3 life-systems technology firms. In addition, 11 considered themselves to be both biotechnology and pharmaceutical firms and the remaining 30 operated in multiple businesses.

With the exception of some minor changes, the same survey instrument was used to create both data sets. Given the similarities in make-up of the sample and the common instrument, the analysis was conducted using the combined sample of both New York and Utah based firms. The data was collected from the CEO (or CEO-equivalent) from each firm via telephone interviews. The response rate for the entire sample was over 80 percent.

\section{Measures}

Innovativeness was measured in terms of the number of patents and trade secrets held by the firms (as another important way of maintaining intellectual property in the bioscience-technology industries). However, there were large discrepancies between the size of firms (with eight firms in the sample having more than 1000 employees). The size of the firm had an effect upon the number of patents (these variables were correlated at $0.28, p<0.01$ ). Therefore, innovativeness was measured by dividing the number of patents and trade secrets by the size of the firm to gain a 'per employee' measure.

To collect information on the source of innovation, respondents were asked about the source of their most three recent innovations, or on all of their innovations, if there had been less than three. The responses were categorized as either internal, from a competitor, a customer, a supplier or other. Given the relatively low numbers of innovation sources that were external to the firm, all external sources were grouped together. Whether innovations were primarily externally or internally sourced was determined in two ways - as an absolute number for each firm, and by calculating the percentage of external/internal innovations in each firm relative to the total number of innovations for which data regarding the innovation source was collected.

As previously discussed, R\&D intensity was used as a proxy for knowledge intensity (which is consistent with the way that knowledge intensive industries are conceptualized). Knowledge intensity was measured in two ways. The first was the total number of man-hours spent on research and development as a percentage of the total number of man-hours within the firm over a given period. Due to some inconsistencies in terms of how certain tasks are classified within firms (e.g., a task may be classified an engineering as it is completed by an engineer when it has a very heavy $R \& D$ element) an additional measure was used; the percentage of total revenue that was spent on research and development.

The collaboration variable was a cumulative measure of formal collaborative arrangements with a range of organizations including universities, hospitals, other 
bioscience-technology firms, other commercial firms, financial organizations/agencies, regulators, public support agencies and other non-commercial firms. The data were collected regarding collaboration for all organizational activities and were not limited to collaboration specifically designed to help in the innovation process. The collaboration measure was gained by adding the number of collaborative arrangements that each firm had with these various organizations.

\section{Results}

The data were considerably skewed across many of the variables. The most noticeable skewing was in relation to the size variable where many of the largest firms were over 1,000 employees (the majority of whom were medical devices firms). While all the firms operated in the bioscience-technology industries, there were considerable differences in variables across the different sectors such as the propensity to innovate/patent and the extent to which the firm engaged in external collaboration. Initial analysis using regression models did not produce useful results as the vast majority of any variance in the dependent variable was attributed to size (which was included in the model as a control variable where appropriate). Where size was not an issue, the extreme variance in some variables created problems. For example, the number of collaborative linkages for most firms was between 5 and 25, but some firms had more than 1,000 linkages in place. The lack of any significant results using regression models would indicate the effects that were hypothesized were either weak, or were confounded by other variables - such as industry sub-sector factors (which could not be effectively controlled for due to the limited sample size).

Our response was to take a more exploratory approach by using independent sample t-tests. To undertake t-tests, some continuous variables needed to be split into dichotomous variables. This was done by splitting the data around the approximate average. Exact average cut-offs were not used as some variables were related and a common cut-off was deemed more appropriate. For example, the percentage of expenditure spent on R\&D activities, and the percentage of manhours spent on R\&D activities were similar and thus a common cut-off of 40 percent was used for both these variables.

\section{Test of Hypotheses}

Hypothesis la was tested by comparing innovativeness for firms considered to be high in relation to their inter-organizational collaborative arrangements and those that were considered to be low across the same dimension. Levene's Test for Equality of Variances $(\mathrm{F}=41.23 p=0.00)$ indicated that equal variances could not be assumed. The results proved to be significant $(p<0.10)$ and showed that firms with high levels of inter-organizational collaboration had considerably more patents and trade secrets per employee (Table 1). Hypothesis 1b used the same collaborative variable and compared the means of the number of externally stimulated innovations per firm, as well as the percentage of external innovations relative to the total number of innovations for which a source was collected for each firm. Both results proved to be significant (Table 1). 
Table 1

Results for Hypothesis 1

\begin{tabular}{|c|c|c|c|c|c|c|}
\hline & Mean & StdDev & $\begin{array}{c}\text { Mean } \\
\text { difference }\end{array}$ & $t$-value & $\mathrm{df}$ & Sig. $(p)$ \\
\hline $\begin{array}{l}\text { Hypothesis 1a-Patents \& } \\
\text { trade secrets (controlled for } \\
\text { by size)^}\end{array}$ & & & & & & \\
\hline High external collaboration & 1.70 & 3.76 & 0.86 & 1.84 & 138 & $0.06^{\dagger}$ \\
\hline Low external collaboration & 0.83 & 1.91 & & & & \\
\hline $\begin{array}{l}\text { Hypothesis 1b-(i) number of } \\
\text { externally stimulated } \\
\text { innovations }\end{array}$ & & & & & & \\
\hline High external collaboration & 1.02 & 1.08 & 0.39 & 2.19 & 161 & $0.03 *$ \\
\hline Low external collaboration & 0.63 & 0.63 & & & & \\
\hline $\begin{array}{l}\text { Hypothesis 1b-(ii) } \\
\text { percentage of externally } \\
\text { stimulated innovations }\end{array}$ & & & & & & \\
\hline High external collaboration & $36.2 \%$ & 32.9 & 14.5 & 2.35 & 161 & $0.02 *$ \\
\hline Low external collaboration & $21.7 \%$ & 37.6 & & & & \\
\hline
\end{tabular}

Hypothesis 2 a tested the means of patents and trade secrets per employee against firms that were high versus low in regards to knowledge intensity. Equal variances could not be assumed as Levene's test for equality of variances produced an F of $10.90(p<0.01)$ for the dollar based-measure and an $\mathrm{F}$ of $12.32(p<0.01)$ for the man-hours measure. Both measures of knowledge intensity provided significant results (Table 2). Hypothesis $2 \mathrm{~b}$ used the same knowledge intensity measures and compared the means of the number of internal innovations and the percentage of internal innovations per firm relative to the total number of innovations. In the two cases where knowledge intensity was measured by the percentage of hours, equal variances were not assumed, as Levene's test for equality of variances produced $\mathrm{F}$ scores of 4.34 and 9.90 (with $p<0.05$ in both cases). The results showed that the knowledge intensity measure of the percentage of total hours committed to R\&D proved to be significant (Table 2).

Hypothesis 3a took firms that had both high levels of inter-organizational collaboration and were knowledge intensive, and compared these to all other firms in relation to innovativeness. Levene's test for equality of variances showed that equal variances can be assumed as $p=0.09$ and the standard cut-off point is 0.05 or less (Ticehurst and Veal, 1999). If equal variances are assumed then the results for Hypothesis $3 \mathrm{a}$ are not significant - though the result is significant if the cut-off point for assuming equality of variances is 0.10 or less (with $p<0.01$ in this case). Hypothesis $3 \mathrm{~b}$ again compared firms that were high in terms of collaboration and 
Table 2

Results for Hypothesis 2

\begin{tabular}{|c|c|c|c|c|c|c|}
\hline & Mean & StdDev & $\begin{array}{c}\text { Mean } \\
\text { difference }\end{array}$ & $t$-value & df & Sig. $(p)$ \\
\hline $\begin{array}{l}\text { Hypothesis 2a-Patents \& } \\
\text { trade secrets (controlled for } \\
\text { by size)^ } \\
\text { High knowledge intensity } \\
\text { (percentage of budget measure) } \\
\text { Low knowledge intensity }\end{array}$ & $\begin{array}{l}2.51 \\
0.87\end{array}$ & $\begin{array}{l}6.29 \\
2.02\end{array}$ & 1.64 & 2.07 & 76 & $0.04 *$ \\
\hline $\begin{array}{l}\text { Hypothesis 2a-Patents \& } \\
\text { trade secrets (controlled for } \\
\text { by size) } \\
\text { High external collaboration } \\
\text { (percentage of total hours } \\
\text { measure) } \\
\text { Low external collaboration }\end{array}$ & $\begin{array}{l}2.52 \\
0.96\end{array}$ & $\begin{array}{l}6.16 \\
1.97\end{array}$ & 1.55 & 1.80 & 67 & $0.07^{\dagger}$ \\
\hline $\begin{array}{l}\text { Hypothesis 2b-(i) number of } \\
\text { internally stimulated } \\
\text { innovations } \\
\text { High knowledge intensity } \\
\text { (percentage of budget measure) } \\
\text { Low knowledge intensity }\end{array}$ & $\begin{array}{l}2.01 \\
1.97\end{array}$ & $\begin{array}{l}1.12 \\
1.13\end{array}$ & 0.04 & 0.25 & 172 & 0.80 \\
\hline $\begin{array}{l}\text { Hypothesis 2b-(i) number of } \\
\text { internally stimulated } \\
\text { innovations ^ } \\
\text { High knowledge intensity } \\
\text { (percentage of total hours } \\
\text { measure) } \\
\text { Low knowledge intensity }\end{array}$ & $\begin{array}{l}2.30 \\
1.87\end{array}$ & $\begin{array}{l}1.00 \\
1.13\end{array}$ & 0.43 & 2.57 & 145 & $0.01 *$ \\
\hline $\begin{array}{l}\text { Hypothesis 2b-(ii) } \\
\text { percentage of internally } \\
\text { stimulated innovations } \\
\text { High knowledge intensity } \\
\text { (percentage of budget measure) } \\
\text { Low knowledge intensity }\end{array}$ & $\begin{array}{l}72.7 \% \\
69.3 \%\end{array}$ & $\begin{array}{l}37.68 \\
37.68\end{array}$ & 3.44 & 0.59 & 172 & 0.55 \\
\hline $\begin{array}{l}\text { Hypothesis 2b-(ii) } \\
\text { percentage of internally } \\
\text { stimulated innovations } \\
\text { High knowledge intensity } \\
\text { (percentage of total hours } \\
\text { measure) } \\
\text { Low knowledge intensity }\end{array}$ & $\begin{array}{l}83.1 \% \\
65.6 \%\end{array}$ & $\begin{array}{l}31.61 \\
38.04\end{array}$ & 17.54 & 3.26 & 152 & $0.00^{* *}$ \\
\hline
\end{tabular}

$+p<.10$

$* p<.05$

$* * p<.01$

$\wedge$ Equal variances not assumed as Levene's Test for Equality of Variances shows unequal variances. For Hypothesis 2a where knowledge intensity was determined by the budget measure, $\mathrm{F}=10.90, \mathrm{p}<0.01$. For Hypothesis $2 \mathrm{a}$ where the knowledge intensity was determined by the percentage of total hours available committed to $R \& D, F=12.32, p<0.01$. For Hypothesis $2 \mathrm{~b}(\mathrm{i})$ where knowledge intensity was determined by the percentage of hours, $\mathrm{F}$ $=4.34, \mathrm{p}<0.05$. For Hypothesis $2 \mathrm{~b}$ (ii) where knowledge intensity was determined by the percentage of hours, $\mathrm{F}=9.90, \mathrm{p}<0.05$. 
Table 3

Results for Hypothesis 3

\begin{tabular}{|c|c|c|c|c|c|c|}
\hline & Mean & StdDev & $\begin{array}{c}\text { Mean } \\
\text { difference }\end{array}$ & $t$-value & df & Sig. $(p)$ \\
\hline $\begin{array}{l}\text { Hypothesis 3a-Patents \& } \\
\text { trade secrets (controlled for } \\
\text { by size) } \\
\text { High external collaboration \& } \\
\text { high knowledge intensity } \\
\text { All other firms }\end{array}$ & $\begin{array}{l}1.63 \\
0.42\end{array}$ & $\begin{array}{l}4.59 \\
0.56\end{array}$ & 1.21 & 1.08 & 164 & 0.28 \\
\hline $\begin{array}{l}\text { Hypothesis 3b-(i) number of } \\
\text { externally stimulated } \\
\text { innovations } \\
\text { High external collaboration \& } \\
\text { high knowledge intensity } \\
\text { All other firms }\end{array}$ & $\begin{array}{l}1.12 \\
0.72\end{array}$ & $\begin{array}{l}1.16 \\
1.00\end{array}$ & 0.40 & 1.53 & 164 & 0.13 \\
\hline $\begin{array}{l}\text { Hypothesis 3b-(ii) } \\
\text { percentage of externally } \\
\text { stimulated innovations } \\
\text { High external collaboration \& } \\
\text { high knowledge intensity } \\
\text { All other firms }\end{array}$ & $\begin{array}{l}41.2 \% \\
24.8 \%\end{array}$ & $\begin{array}{l}41.7 \\
34.4\end{array}$ & 16.33 & 1.81 & 164 & $0.07^{\dagger}$ \\
\hline
\end{tabular}

${ }^{+} p<.10$

knowledge intensity with the other firms, in terms of the total number of innovations that were externally stimulated and the percentage of external innovations relative to the total number of innovations for which an innovation source was identified. Only the percentage of externally stimulated innovations proved to be significant (Table 3).

\section{Discussion}

This study sought to fulfill two aims: (i) to further our understanding as to why it is that some firms are more innovative than other firms, and (ii) to appreciate whether inter-organizational links and knowledge intensity have an effect upon the source of innovations developed by firms. In respect of these two aims, the results could at best be described as relatively weak with only broad trends being discerned in a limited number of hypotheses.

The hypotheses were initially set up to be tested using regression models. When this was done, however, none of the results obtained proved to be significant. In short, the relationships that were predicted, if correct, are subject to many other factors that were not able to be tested on the basis of the collected include din our analysis. Innovation is a complex interactive process and the "factors that relate to innovation are many and varied, and can change over time" (Caloghirou, Kastelli, and Tsakanikas, 2004: 30). This complexity is likely to have affected this study; 
and, as just one example, there are significant industry sub-sector differences within this biosciences sample - most likely because of variations in the basic business models for these different industry sub-groups. For example, patents and trade secrets would seem to be more important in the life systems technology area with an average of 54.8 patents and trade secrets per firm. This compares to an average of only 28.2 per firm for medical devices firms. These differences become even more pronounced when size is taken into account as life systems firms have an average of 55.6 people, whereas medical devices firms have an average of 201.8 people.

Similarly, in terms of the percentage of hours spent on R\&D across the entire firm, biotechnology firms were the most knowledge intensive, committing 43 percent of their total time to $R \& D$, whereas life systems firms were the lowest (with only 19 percent). In some respects this is surprising given the innovativeness of the life systems firms, however, in this respect it is worth noting that life systems firms had the lowest number of internally stimulated innovations (for which data was collected) of all the different sub-groups. In comparison, internally sourced innovations were most common in pharmaceutical firms.

Certainly there would seem to be basic differences across the different types of firms and these differences are likely to reflect different business models. These, and other factors, are likely to be responsible for the lack of significant results in respect of any regression models. Theoretically, segregating out the different industry sub-sectors would have allowed for us to control at least the industry subsector effects, however, with the exception of the medical devices firms and those that operated in multiple industry sub-sectors, the sample sizes were simply too small. Interestingly, regression analyses for just medical devices produced significant results for the knowledge-intensity related hypotheses, though they are not discussed here, as our hypotheses never suggested that differences would be found across different industry sub-sectors, but rather we were seeking results that could be generalized across the bioscience-technology industries as whole. In terms of the firms that operated in multiple sub-sectors, there was no commonality in terms of the data as firms took on the characteristics of many different sub-sectors. For example, some firms were principally biotechnology firms with some pharmaceutical component, whereas others were medical devices firms with a small life sciences business.

Due to our lack of significant results through regression, we used independent sample t-tests to test our hypotheses. By grouping firms into high and low categories, we were able to limit some of the extreme variance that existed in relation to some variables. The results are certainly much weaker and should be interpreted with some degree of caution. The basic trends that were observed, however, suggest that some hypotheses may have a degree of validity.

\section{Hypothesis Discussion}

Collaborative linkages with external organizations have taken on an increasing level of importance within various innovation models of late (e.g., Rothwell, 1992; Tang, 1998). Such emphasis would seem to be well placed, as firms that were considered to be high in this dimension were approximately twice as innovative 
(after controlling for the effect of size). Obviously, not all collaborative relationships are designed to enhance innovativeness, and in fact the number, type and effect of different collaborative relationships, did differ between the various subgroups. Nevertheless, there does seem to be a relationship between a firm's innovativeness and the extent of its external collaborative linkages.

The other factor that affected innovativeness was knowledge intensity. Firms that invested heavily in research and development (in terms of the percentage of overall budget or in terms of the percentage of total man-hours contributed to the R\&D function) were approximately three times more innovative than firms considered to be low in knowledge intensity.

These two results suggest that technological innovation is not the "impossibleto-map" and "black-box" type of process that it is sometimes described as being. Certainly, it is not a random event that is mostly to do with luck, such as getting the right people at the right time. Rather, there are definite purposeful strategies that can be undertaken to improve a firm's innovativeness. Investing in external collaborative relationships and building the knowledge intensity of a firm are not short-term (or cheap) strategies, but the order-of-magnitude difference between firms that were considered to be high in this dimension, relative to the low performing firms, is such that these strategies must be at least considered amongst the various alternatives available to firms in high innovation industries.

Interestingly, firms that were both knowledge intensive and high in external linkages were not significantly more innovative. This, however, is more likely a small-numbers effect as the mean number of innovations for such firms is almost four times as high as others. However, a tiny sample size of 17 reduced our ability to make any meaningful comment in relation to Hypothesis $3 \mathrm{a}^{2}$

Part $b$ of the three hypotheses considered the different sources of the innovations. External collaborative linkages were linked to higher levels of externally sourced innovations, and more knowledge intensive firms had marginally higher levels of internally sourced innovations (although, in this case, only the percentage of total hours devoted to R\&D produced a significant result). Where both strategies were present (high collaboration and high knowledge intensity) the level of externally stimulated innovations was higher. Overall, this sample was dominated by internally stimulated innovations, but there were significant differences between the percentage of internally and externally stimulated innovations according to firms' collaborative linkages and knowledge intensity. This result certainly builds upon von Hippel's (1988) earlier work regarding economic rents, to suggest that firmlevel strategies also have a significant role to play in determining the source of innovation. That is, the source of innovation is not just determined by industry structure, but can be purposefully affected by firm-level strategies.

A natural question that emerges from this analysis is whether external collaborative linkages with other firms can be used as a substitute for investment in $\mathrm{R} \& \mathrm{D}$, or vice versa? After all, both highly linked firms and knowledge intensive firms were considerably more innovative than firms rated as low across these two dimensions. In this particular sample, there were only 17 firms that were high in both dimensions - meaning that there were 89 firms that were high across just one dimension. So, are firms investing in collaborative linkages as a substitute to R\&D (or vice versa)? It is possible. Firms that were considered to be high in collabora- 
tive linkages had 36.2 percent of their innovations stimulated externally, versus only 21.7 percent for those firms considered to be low across this dimension. Taking the results of Hypothesis $2 \mathrm{~b}$ (ii) - man-hours measure of knowledge intensityshows that knowledge intensive firms produced 83.1 percent of their innovations from internal sources versus only 65.6 percent for low knowledge intensity firms. Yet both of these strategies were associated with firms being significantly more innovative.

These results, and the fact that both strategies lead to greater innovativeness, may mean that choosing either external sourcing of innovation or internal generation of innovation is a purposeful decision on the part of managers. However, it may also be a function of industry dynamics whereby some sub-sector firms are more internally focused (e.g., pharmaceutical firms) and other sub-sectors tend towards the externally focused strategy of establishing inter-firm linkages (e.g., biotechnology firms). The sample size did not allow the different sub-sectors to be adequately investigated in this regard. However, the possibility of these strategies forming alternatives in improving innovativeness is certainly worthy of further investigation.

\section{Limitations}

There are three major limitations to this study. These limitations relate to the data collected, the sample, and the data analysis techniques. This study focused upon the innovativeness of firms and the sources of these innovations. The data for neither of these measures was perfect. In relation to innovativeness, this study used self-reported patent counts and trade secrets. While patent counts are commonly used as a proxy for innovation (e.g., see Griliches, 1987) not all innovations would necessarily be picked up by a patent and trade secret count. Patent and trade secret numbers are also likely to be affected by size (for which we controlled) and to a lesser extent by age (for which we did not control) - with older firms likely to have more patents and trade secrets.

In relation to the sources of innovation, firms were asked about the sources of their three most recent innovations (or less than three if they had not produced three innovations). Detailing the source of innovation is often difficult, and requires some discussion, and it is for this reason that data on such a limited number of innovations were collected. The obvious limitation is that the pattern of sources for these three most recent innovations may not mirror the overall pattern found within the firm, or even across the industry (though differences at the industry level are more likely to be averaged out). Nevertheless, this study assumes that our limited sample of innovation sources pattern matches the overall industry pattern.

The second limitation relates to the sample and has already been alluded to in that the different sub-sectors within the bioscience-technology industries would seem to have noticeable differences. While the study was always designed to include the breadth of the bioscience-technology industries for the purposes of improving generalizability, it may be that the industry sub-sector level differences may have been part of the reason for the lack of significant regression results (discussed below). At the same time, the fact that the sample covered just the bioscience-technology industries means that the results are highly limited as to the 
extent to which they can be generalized. Innovation is a highly esoteric process and the sources, types and general level of innovation is likely to differ significantly between industries (e.g., von Hippel's (1988) study). Therefore, these results really need to be interpreted as applying specifically to the bioscience-technology industries (in the context of the US environment).

Finally, as previously discussed, the analysis techniques relied upon in this study were limited to independent sample t-tests. To do this, continuous variables were converted into dichotomous variables according to approximate mean splits. This reduced the power of the analysis, as it eliminated much of the natural variance found in the raw data. This step was undertaken because extreme levels of variance created a situation where no significant results were found when using the typically preferred regression based analysis. Thus, the results from the t-tests need to be interpreted as relatively weak; and we need to be cognizant of the fact that other variables are at work that substantially affect the innovation process.

\section{Conclusion}

Technological innovation is not a random process, but is rather a complex interactive process that is affected by a range of both internal and external influences. As each situation tends to be relatively unique, it is often difficult to summarize what it is that makes some firms more innovative than others and from where innovations will be sourced. Therefore, this study eliminated much of the possible variance to concentrate upon the effect of external collaborative linkages and knowledge intensity upon innovativeness and the sources of innovation in the biosciencetechnology industries. Both of these strategies had a significant effect upon innovativeness. In addition, high levels of external linkages were linked to relatively higher levels of externally stimulated innovations, and high knowledge intensity was related to significantly higher levels of internally stimulated innovations. Where firms had both high external linkages and high knowledge intensity, the percentage of externally stimulated innovations were significantly higher, suggesting that the absorptive capacity created by high investments in $R \& D$ allowed for more of the knowledge that came from partner firms was able to be assimilated and applied to developing innovations.

For managers, these results have significant implications. Firstly, it demonstrates that investing in R\&D and external linkages does have a pay-off in terms of innovativeness. These are not cheap strategies, but it may be worth noting that firms that do not have the time or the resources to initially ramp up their investment in R\&D can expect significant payback from investing in inter-organizational relationships. If this becomes a core strategy of some firms, it will have significant effects upon the operation of the business, ranging from who is hired to how performance is measured. Also, of note to managers, is the fact that high investment in R\&D and numerous external linkages do not have to occur simultaneously, as both strategies improve innovativeness independently of each other.

Given that very few firms had numerous external linkages, and also invested significantly in $R \& D$, an area for future research would be to investigate whether these strategies could be used as substitutes for each other, or whether they should best be treated as complementary strategies? Or, alternatively, is the usefulness of 
the strategy dependent upon the industry segment, with some industry segments relying upon a diverse range of knowledge that are most appropriately accessed through external linkages, and other industry segments' innovations being more incremental and sequential, therefore being best completed in-house. Our research did not answer this question. However, it did demonstrate the importance of both internally oriented strategies and externally oriented strategies as sources of innovation.

\section{Notes}

1. The term "bioscience-technology industries," as used here, was taken from the work of Willoughby (1997). This industry category includes not only biotechnology firms but also firms active in medical devices technology, pharmaceuticals technology, and other fields of technology related to the life-sciences. Elsewhere, the term "life sciences industries" is sometimes used to refer to this set of technology-based firms and activities.

2. In fact, if the cut-off point for not assuming equal variances was taken as $p<0.10$ rather than $p$ $<0.05$ then the corresponding t-test is significant ( $\mathrm{t}$ value $=3.01, p<0.05$ ). Given the very small sample size in this case, their may be an argument in favor of adopting the higher cut-off, which would make Hypothesis 3a significant.

\section{References}

Alam, I. (2003). Commercial Innovations from Consulting Engineering Firms: An Empirical Exploration of a Novel Source of New Product Ideas. The Journal of Product Innovation Management 20, 300-313.

Arora, A., Fosfuri, A. and Gambardella, A. (2001). Markets for Technology. Cambridge, MA: MIT Press.

Autio, E., Sapienza, H. J. and Almeida, J. G. (2000). Effects of age at entry, knowledge intensity, and limitability on international growth. Academy of Management Journal 43, 909-924.

Brown, S. L. and Eisenhardt, K. M. (1995). 'Product Development: Past Research, Present Findings, and Future Directions. Academy of Management Review 20, 343-378.

Caloghirou, Y., Kastelli, I. and Tsakanikas, A. (2004). Internal capabilities and external knowledge sources: complements or substitutes for innovative performance? Technovation 24, 29-39.

Chiesa, V. and Toletti, G. (2004). Network of Collaborations for Innovation: The Case of Biotechnology. Technology Analysis \& Strategic Management 16, 73-96.

Clark, K. B. and Wheelwright, S. C. (1992). Organizing and leading "heavyweight" development teams. California Management Review 34(3), 9-28.

Cohen, W. M. and Levinthal, D. A. (1990). Absorptive Capacity: A New Perspective on Learning and Innovation. Administrative Science Quarterly 35, 128-152.

Dodgson, M. (1994). Technological Collaboration and Innovation, in M. Dodgson and R. Rothwell (Eds.), The Handbook of Industrial Innovation, Cornwall: Edward Elgar, 285-292.

Eisenhardt, K. M. and Tabrizi, B. N. (1995). Accelerating Adaptive Processes: Product Innovation in the Global Computer Industry. Administrative Science Quarterly 40, 84-110.

Freeman, C. (1991). Networks of innovators: A synthesis of research issues. Research Policy 20, 499-514.

Gambardella, A. (1992). Competitive advantages from in-house scientific research: The US pharmaceutical industry in the 1980s. Research Policy 21, 391-407.

Goes, J. B. and Park, S. H. (1997). Inter-organizational Links and Innovation: The Case of Hospital Services. Academy of Management Journal 40, 673-696.

Grant, R. M. (1996). Towards a Knowledge-based Theory of the Firm. Strategic Management Journal 17(Winter Special Issue), 109-122.

Griliches, Z. (1987). R\&D, Patent and Productivity. National Bureau of Economic Research. Chicago: The University of Chicago Press.

Gulati, R. (1995). Social Structure and Alliance Formation Patterns: A Longitudinal Analysis. Administrative Science Quarterly 40, 619-652. 
Hamel, G. (1991). Competition for Competence and Inter-partner Learning within International Strategic Alliances. Strategic Management Journal 12, 83-103.

Hauschildt, J. (1992). External Acquisition of Knowledge for Innovations-A Research Agenda. $R \& D$ Management 22(2), 105-110.

Herstatt, C. and von Hippel, E. (1992). Developing New Product Concepts via Lead User Method: A Case Study in a "Low-Tech Field". Journal of Product Innovation Management 9, 213-221.

Josty, P. L. (1990). 'A Tentative Model of the Innovation Process', R\&D Management 20(1), 35-45.

Kahn, K. B., Franzak, F., Griffin, A., Kohn, S. and Miller, C. W. (2003). Editorial: Identification and Consideration of Emerging Research Question'. Journal of Product Innovation Management 20, 193-210.

Khanna, T., Gulati, R. and Nohria, N. (1998). The Dynamics of Learning Alliances: Competition, Cooperation and Relative Scope. Strategic Management Journal 19, 193-210.

Khurana, A. and Rosenthal, S. R. (1998). Towards Holistic 'Front Ends' in New Product Development. Journal of Product Innovation Management 15, 57-74.

Kogut, B. (1988). A Study of the Life Cycle of Joint Ventures, in F. Contractor and R. Lorange (Eds.), Cooperative Strategies in International Business, New York: Lexington Books, 169-185.

McAdam, R. and McClelland, J. (2002). Sources of new product ideas and creativity practices in the UK textile industry. Technovation 22, 113-121.

Mowery, D. C., Oxley, J. E. and Silverman, B. S. (1996). Strategic Alliances and Interfirm Knowledge Transfer. Strategic Management Journal, 17, (Special Winter Issue), 77-91.

Myers, S. and Marquis, D. G. (1969). Successful Industrial Innovation, Washington DC: National Science Foundation.

Nonaka, I. (1994). A Dynamic Theory of Organizational Knowledge Creation. Organization Science 5, 14-37.

Nonaka, I. and Takeushi, H. (1995). The Knowledge-creating Company. Oxford University Press: New York.

Osland, G. and Yaprak, A. (1995) Learning Through Strategic Alliances: Processes and Factors that Enhance Marketing Effectiveness. European Journal of Marketing 29, 52-66.

Quinitas, P., Wield, D. and Massey, D. (1992). Academic-industry links and innovation: questioning the science park model. Technovation, 12, 161-175.

Rothwell, R. (1992). Successful Industrial Innovation: Critical Factors for the 1990's. R\&D Management 22, 221-239.

Shaw, B. (1986). Appropriation and Transfer of Innovation Benefit in the UK Medical Equipment Industry. Technovation, 4 ,

Shaw, B. (1993). Formal and Informal Networks in the UK Medical Equipment Industry, Technovation, 13,6 ,

Sunman, H. (1987). Science Parks, Technopoles and Innovation Centres: The European Experience. Int. J. of Technology Management, 2, 142-145.

Tang, H. K. (1998) An Integrative Model of Innovation in Organizations. Technovation, 18, 297-309.

Teece, D. J. (1989). Innovation and the Organization of Industry. CCC Working Paper 90-6. Centre for Research in Management, University of California at Berkeley.

Ticehurst, G. W. and Veal, A. J. (1999). Business Research Methods: A Managerial Approach, Sydney: Addison Wesley Longman Australia.

Von Hippel, E. (1978). Successful Industrial Products From Customer Ideas. Journal of Marketing 42, 39-49.

Von Hippel, E. (1988). The Sources of Innovation, New York, Oxford, Oxford University Press.

von Krogh, G., Roos, J. and Slocum, K. (1994). An essay on corporate epistemology. Strategic Management Journal 15, 53-71.

Willoughby, K. W. (1997). New York's Evolving Bioscience Technology Industries: Managing Knowledge, Production and Services for Economic Development. Stony Brook, New York: State University of New York, Center for Biotechnology, 1997.

Willoughby, K. W. (2004). The Affordable Resources strategy and the Milieux Embeddedness strategy as alternative approaches to facilitating innovation in a knowledge-intensive industry. Journal of High Technology Management Research 15, 91-121. 
Copyright of Knowledge, Technology \& Policy is the property of Transaction Publishers. The copyright in an individual article may be maintained by the author in certain cases. Content may not be copied or emailed to multiple sites or posted to a listserv without the copyright holder's express written permission. However, users may print, download, or email articles for individual use. 